\title{
THE EFFECT OF SCAVENGER HUNT GAME ON STUDENTS' READING COMPREHENSION OF DESCRIPTIVE TEXT
}

\author{
Mike Amelia ${ }^{1}$ \\ Universitas Bina Sarana Informatika \\ Nostalgianti Citra Prystiananta ${ }^{2}$ \\ IKIP PGRI Jember \\ ameliamike@yahoo.co.id ${ }^{1}$
}

Submit, 13-06-2020 Accepted, 21-06-2020 Publish, 24-06-2020

\begin{abstract}
This research had purpose to find out whether there was a positive effect of scavenger hunt technique on students' reading comprehension of descriptive text. Scavenger Hunt is a fact-finding and information-processing activity, where the students work in group to search for hidden items and perform task by using some clues.The method used in this research was quasi-experimental research. This research was conducted at the eighth grade students of SMP N 2 Kota Solok. The samples of this research were two homogeneous classes that chosen by using purposive sampling technique. The experimental class was taught by using scavenger hunt technique, meanwhile the control class was taught by using three phase technique. The technique of gathering the data of this research was by using reading test. The result of this research showed that there was a positive effect of implementation scavenger hunt technique, where the mean score at experimental class was 77,14 and control class was 72,94 . Thus, the experimental students outcomes were higher than the control class.It means that students' reading comprehension of descriptive text taught by using Scavenger Hunt game technique was better than taught by using three phase technique.
\end{abstract}

Keywords: Scavenger Hunt, Reading Comprehension, Descriptive Text

\section{INTRODUCTION}

Reading comprehension refers to reading for meaning, understanding, and entertaining. Reading comprehension is a complex process of understanding the meaning of printed words and also to get the meaning of the material in analyzing sentences based on the reader ability to find the meaning and main information from what the reader read before. It involves higher-order thinking skills that more complex than merely decoding specific words. Therefore, it is not an easy task for the teacher to teach reading comprehension. Nunan (2005) says that reading comprehension refers to reading for meaning, understanding, and 
entertaining. It involves higher-order thinking skills and is much more complex than merely decoding specific words. The essential part of the reading process is deriving meaning, analyzing and synthesizing what we have read. It means that reading comprehension is a complex steps of reading for meaning, understanding, and entertaining.

According to Zainil in Aulia (2013) divides that there are three essential parts in understanding paragraph in reading comprehension. The first is identifying the topic. The topic is the one thing a paragraph tells about. Every sentence in a paragraph in some way discusses or explains the topic. The second is finding the main idea. The main idea of a paragraph is all about what the author wants tells about the topic. The third is recognizing supporting details. Supporting details as the facts and ideas that prove or explain the main idea of paragraph. Supporting details in a paragraph do support the main idea, not all details are equally important.

In recent curriculum, reading competency at Junior High School, there are some expectation to be achieved by the students. The students are expected to comprehend or understand the information, social function, structure, and grammar of the texts. Based on syllabus of eighth grade at Junior High School, the students are taught several kind of texts. They are recount, descriptive, and narrative text. Among the texts that should be learned by Junior High School students is descriptive text. Descriptive text is a text that describes detail characteristic of something. Suryana (2008) explains that descriptive text is a text that has function to describe characteristic of person, noun and place. It means that descriptive text is a text that describes information about characteristic of person, noun, place and so on. In this text, the writer tries to express his/her idea by giving clear explanation about something for the reader. In addition, Kurniawati (2008) states that the generic structure of descriptive text consists of description and identification part.

The writer introduces the subject in identification part generally. In the description part, the writer mentions or clarify characteristic of subject, for example physical appearance, qualities and general attitude. However, there are many problems occurred in the process of teaching and learning reading comprehension especially in descriptive text. In this case, the researcher assumes that using Scavenger Hunt Game technique is one of a good one to solve the problems.

Regarding to research on using scavenger hunt game, there were some researchers conducted research that considered relevant to this research as follow:the first is the research conducted by Shaleha (2017), the objective of her research is to find out whether the use of Scavenger Hunt Game could develop the ability of grade eight students in reading comprehension. The study confirms that 
reading comprehension was developed significantly after applying Scavenger Hunt Game, It is supported by seeing the mean scores of pre-test and post-test in experimental class. It indicates that reading comprehension of the students is significantly developed after getting the treatment. In addition, there is a significant difference between mean scores in pre-test and post-test. This research also supported by Sari (2016), the result of the study showed that the students' mean score improve in the second cycle. It means that students comprehension in reading text improve significantly after using scavenger hunt game.

In other case, scavenger hunt games is also become one of effective ways in teaching vocabulary as conducted by Anengsih (2017), the research provely that students can increase the vocabulary in long term memory, students better discuss and write about school topics when they can easily remember vocabulary. As inclusion settings become more popular, students with learning disabilities become increasingly challenged with learning and retaining material from the general education curriculum. Understanding vocabulary words and how they relate to other ideas and concepts greatly impacts and influences reading comprehension. After the data has been analyzed, the writer conclude that in eight students to the implementation of treasure hunt game, there is a chance that students may get confused while using the treasure hunt game because each student learns in a different way and not all teaching tools may work the same. One student may be more confused when connecting a ,treasure hunt ${ }^{\text {ee }}$ to a vocabulary word and accidentally recall the, ,treasure hunt $t^{\text {ee }}$ and forget the definition, while another student may remember easier when using a „treasure hunte to jog his or her memory.

Every student learns differently, especially when you are teaching special education. In line with this, Satya (2016) has conducted the research with aimed to find out the effectiveness of Treasure Hunt game for teaching vocabulary .After the analysis, the research showed a significant improvement in the students' vocabulary mastery. It is supported by the t-test result which was higher than $\mathrm{t}$ table. The research conclude teaching vocabulary using Treasure Hunt game was effective. Then Wulan (2015), investigates the students' responses to the teachinglearning activity of the use of Scavenger Hunt in teaching vocabulary. The results of the study are: (1) the teaching-learning process consists of indoor activities and outdoor activities involving the stage of learning, namely engaging, studying, activating, and closing; (2) the students enjoy doing activities and they are interested in joining the teaching-learning process; (3) the students are encouraged and motivated to learn more, and (4) the students also have learning experience through indoor activities and outdoor activities. This research also in line with Nurhayati (2017), her research was aimed to find out whether treasure hunt game is effective to be implemented in teaching young learners' vocabulary skill. In 
addition, it is also aimed to know the students' responses to the implementation of treasure hunt game in teaching vocabulary. The study confirms that the implementation of treasure hunt game is effective to be implemented in teaching young learners' vocabulary skill.

Scavenger hunt games is not also can be used in teaching reading or vocabulary but it also can be used in teaching speaking as mentioned by research that has been conducted by Aminuddin (2017) the research shows that students who had good score in English class are not always had a good ability to speak English. Hence, to reach the target of teaching learning process, there must be an effective teaching strategy that can overcome the problems above. This research was concerned on the application of Scavenger Hunt Game in solving students' practical problem of speaking. The Scavenger Hunt game in fact was an outdoor full day game usually used for outbound game. The result of implementing the Scavenger Hunt Game showed that the strategy was effective to solve students' speaking problems. It required two cycles to be successful. Thus, based on the result of cycle 2 the Scavenger Hunt Game is an effective technique used to solve student's practical problems in learning speaking.

Next researcher investigates the procedure of teaching vocabulary using scavenger hunt and to know the students' responses teaching-learning activity of the use of scavenger hunt in teaching vocabulary as conducted by Wulan (2015) and she investigates that the students understand vocabulary words and how they relate to other ideas and concepts greatly impact and influences reading comprehension by using Treasure Hunt Game.

Furthermore, many researchers have been conducted research about the implementation of scavenger hunt game in technology. Talton et al. (2006) investigated that the scavenger hunt concept by incorporating handheld computers to run scavenger hunt games with incoming freshmen for the purposes of orientation and retention. They also found that playing the game improved the attitude of new students. Then, the Mobile Technologies Group (2004) at Georgia Institute of Technology developed a cell-phone based scavenger hunt for student orientation in which students had to interact with local merchants, scour the library, and discover the hidden relics and monuments on campus. The study also provides an example of gamification to enhance teaching and learning. Gamification takes the essence of games - attributes such as fun, play, transparency, design and competition - and applies these to a range of real-world processes inside an organization, including learning and development (Meister, 2013). Scavenger hunts have become one of the most popular tools for teaching students how to use available resources and information (Starr, 1999). Hunts can be tailored to virtually any curriculum area, simultaneously providing students 
with technological and subject matter knowledge, and they can be as simple or involved as circumstances dictate.

As Ly \& Carr (2010) point out without experiencing the physical library, students often lack the understanding of the organization of information, may not use library resources, and possess poor research skills. Improving the quality of library orientation can alleviate library anxiety and improve student learning and also he found that The scavenger hunt game project serves to show how technology can be used to add an educational component to even common games, increasing their educational value and making them more engaging for users.

However, not all skill are convenient to be used by using scavenger hunt game in a teaching english, especially in teaching reading that needs effort to comprehend and find the ideas in the text even explicit and implicit massages. In this case it needs a game involves all sensory nerves such as sight, kinesthetic auditory and verbal. The treasure hunt game is a convenient game to teach reading. Most of the experts above are successful in conducting their research by using the scavenger hunt games but in this case researcher is interested to use scavenger game in reading skill and more specific text (descriptive text) in order to find new fact and to enrich teaching strategy in learning environment.

\section{LITERATURE REVIEW}

Lee (1995) lists several main advantages when games are used in the classroom, including "a welcome break from the usual routine of the language class", "motivating and challenging" "effort of learning", and "language practice in the various skills." Ersoz (2000) holds that games are highly appreciated thanks to their amusement and interest. Teachers can use games to help their students practice more their skills of communication, it is also supported by Koksal, cekic and Behyan (2014) confirms that games could stimulate students' interest in learning.

Scavenger hunt is one of many different types of game which can have one or more players who try to find hidden articles, locations or places by using a series of clues. The implementation of Scavenger Huntwouldhelpthe students in understanding descriptive text. In fact, the given clues are in the form of descriptive text. Whether it describes the hidden items or where its located. For further understanding, some experts define the concept of Scavenger Hunt as follow:

According to Barkley (2010), scavenger hunt is an activity that engaged learners in fact-finding and information-processing exercises using instructorspecified clues. This activity challenges learners to locate and think about the location of the items. The learners' knowledge expand by processing the information from the clues and the enganging task. 
Moreover, Sigridur (2010) viewsthat scavenger hunt as a game where the students would have to solve such as puzzles or questions, in order to search for hidden articles. Also, the clues in scavenger hunt gamewere written in the target language, which forces the participants to read and fellow team members to listen and test their understanding. This idea supported by WRO (2015) who says that scavenger hunt is when explorers may wander around while attempting to find what they are looking for. Clues are available regarding the environment and the location of each of the artifacts to collect. The explorers might work together in order to find the hidden artifacts.

Furthermore, Lu et all (2015) saythat scavenger hunt is a popular game where the organizers define a list of objects or tasks for players to find or perform. However, the players have to find or perform task within a set time limit. When the individual or team participants find objects and perform tasks, they collect the found objects. In the line with Lu, Starr in Lu et all (2015) states that scavenger hunt is a tool for teaching where the students use available sources or information to face problem. It has become one of the most popular tools for teaching students how to use available resources and information. It teaches students how to face or solve problems by using the information (clues) that given to them.

Wise (2003) states that: Scavenger Hunt is a game in which the organizers prepare a list defining specific items, which the participants - individual or teams - seek to gather all items on the list - 3 usually without purchasing them or perform tasks or take photographs of the items, as specified.

The teacher can apply different steps in the application based on the goal of the lesson itself. Sigridur (2010) illustrates that the steps and rules of mini Scavenger Hunt game in the classroom. First, each team is named after a certain color and at each station there are envelopes, one for each team. Each envelope is labeled with the color of a team. Then, within each envelope there are instructions for what the team has to do in order to find the next envelope. When they do, they will have to solve some other assignment in order to get the next one. Next, in order to finish, teams must find all the envelopes and finish all the assignments. The team that is first to complete everything wins.

In conclusion, the researcherapplied the procedure and rule of Scavenger Hunt as follow: first, the teacher hid flashcards throughout classroom. Second, the teacher explaint briefly about descriptive text andthe components. Third, the teacher divided the class in 5 groups based on colors. Fourth, the teacher explaint the procedureand rule of the game. Fifth, the teacher placedthe worksheet about "My Favorite Mug" text and the first clue that described the first hidden flashcard (book) on each group home base. Sixth, the groups searched for the book and when they found it, they asked the teacher for the first instruction handout thatconsisted of explanation and exampleabout topic and main idea. Seventh, 
when they were done identifying the topic and main idea of the text, they showed it to the teacher. Eighth, the group searched for the second hidden flashcard (apple) and when they found it, asked the teacher for the second instruction handout that consisted of explanation and example about supporting detail. Ninth, it continued until they found all of the hidden flashcards and done the task. Tenth, the teacher and the groups discussed the answers together. Last,the teacher decided the winner who collected the right items, has a good teamwork and finished the task.

\section{RESEARCH METHOD}

This research was conducted by using quasi experimental design. The population in this research was the eighth grade students of SMP N 2 Kota Solok. There were 384 students. The researcher used purposive sampling to determine the samples of the research. In this research, the sample was two homogeneous classes that selected as experimental and control class after analyzing the result of English final examination. In this research the researcher do some steps: preparation, pre-test activity, implementation activity in both experimental and control class and compare the result of the class and the last researcher did post test and finally conclude the result of the research.

\section{Preparation}

The researcher did some preparations before doing the research. These preparations included: first, preparing the syllabus of the eighth grade, lesson plan for experimental and control class, and instrument (reading test) that were used in the research. Second, preparing the teaching material about descriptive text that was taught. Third, preparing the supporting media such as flashcards/clucards, and instruction handouts that was appropriate with the material chosen. The flashcards were consisted of pictures of hidden items at the front and clues for the next hidden items at the back. Meanwhile, instruction handouts were consisted of explanation and example of the eight indicators of reading comprehension of descriptive text in a text entitled "My Sphynx Cat". These all set of learning were corrected firstly by the advisors for its validation.

\section{Pre-test}

The researcher conducted pre-test the both of experimental class that was VIII 8 and control class that was VIII 9. The instruments and items in the experimental class were the same with control class. The purpose of pre-test was to find out the students' reading comprehension before the treatment. 


\section{Implementation}

The implementation of this research was done in two classes. They were experimental class and control class. Both of experimental class and control class were given the same material, but each of class got different treatment. The experimental class was taught by using Scavenger Hunt Game technique and control class was taught by using Three Phase technique. In this research, there were 4 meetings and the time allocation was 40 minutes for each meeting.

\section{Experimental Class (Scavenger Hunt technique)}

\section{Pre-teaching activities}

a. The teacher greet the students and leads to pray

b. The teacher checked students' attendance

c. The teacher gave motivation

d. The teacher introduced the competence that students should achieve in the end of lesson that is students were required.

\section{Whilst-teaching activities}

a. The teacher hid the cluecards (flashcards with the pictures of books, apples, hats, bags, and pencil cases at the front and the clues for the next flashcards at the back) throughout the classroom.

b. The teacher explained briefly about descriptive text \&it's components (topic, main idea, supporting detail, purpose, generic structure, and language feature).

c. The teacher divided the class in several groups based on colors, 5 until 6 students for each group.

d. The teacher explained the procedures \& rules of Scavenger Hunt game (the groups should identified the component of a descriptive text called "My Favorite Mug" by looking through the instruction handouts that consisted of the meaning of each component \& example of it in the text called "My Sphynx Cat"; which given by the teacher if only the group had found the hidden flashcards by the help of the given clues).

e. The teacher placed the worksheet \& the 1 st clue that described the 1 st hidden flashcard (book) on each group home base. (The teacher role as controler here who kept a watch on the students' activities and provider who handed the instruction handouts. It means the teacher has a good classroom management and and this technique was appropriate).

f. The groups searched for the book \& when they found it, they asked the teacher for the 1 st instruction handout that consisted of explanation \& 
example about topic \& main idea. (These handouts helped the students to comprehend the components of descriptive text. It also helped them to determine the generic structure of descriptive text and increased their knowledge of adjective words).

g. The group identified the topic \& main idea of "My Favorite Mug" text, then they showed it to the teacher. (Sharing ideas or discussing in group, also help the students in determining the generic structure of descriptive text and increasing their lack knowledge of adjective words).

h. The group search for the 2 nd hidden flashcard (apple) \& when they found it, they asked the teacher for the 2nd instruction handout (consisted of explanation \& example about supporting detail).

i. It continued until they found all of the 5 hidden flashcards and identified the 8 components of the text called "My Favorite Mug".

j. The teacher \& the group discussed the answers together.

$\mathrm{k}$. The teacher decided the winner who collected the right items, has a good teamwork and finished the task.

\section{Post teaching activities}

a. The teacher asked difficulty in learning process

b. The teacher and the students concluded the lesson together

c. Teacher gave the students homework.

\section{Pre-teaching activities}

\section{Control Class \\ (Three Phase technique)}
a. The teacher greet the students and leads to pray
b. The teacher checked students' attendance
c. The teacher gave motivation
d. The teacher introduced the competence that students should achieve in the end of lesson that is students were required.

\section{Whilst-teaching activities}

\section{a. Pre-reading}

1) The teacher explained briefly about descriptive text and it's components (topic, main idea, supporting detail, purpose, generic structure, and language feature).

2) The teacher selected several words from a descriptive text entitled "My Sphynx Cat" and wrote the selected words on the board. (selected words: pet, funny, tail, and fur). 
3) The teacher asked the students to guess the topic of the material (descriptive text) that they going to learn today based on the selected words. (topic: the writer's Sphynx Cat), then the students tried to guess the words until they finally guessed the topic.

4) The teacher distributed the text called "My Sphynx Cat" to the students.

b. Whilst-reading

1) The teacher asked the students to read the text. While the students were reading, the teacher asked them to scan for the selected words in the text.

2) The students mentioned the words and discussed what their meaning with the teacher. (pet means peliharaan, funny means lucu, tail means ekor, and fur means bulu).

3) The teacher asked some of the students to read the text aloud, after that the teacher read the text aloud and the students repeated after her.

4) The teacher asked the students if there was any difficult words that they did not get its meaning. If there was a difficult words, the class discussed what the word means together and if there was not, the teacher continued the learning process to checking the students understanding.

c. Post-reading

1) The teacher distributed the worksheet that consisted of comprehension questions of the text entitled "My Sphynx Cat" (total: eight multiplechoice questions).

2) Each student anwered the questions by them selves and they were allowed to use dictionary if necessarily needed.

3) After they finished it, the teacher \& the students discussed the answers together.

\section{Post teaching activities}

a. The teacher and students concluded the lesson together

b. Gave feedback to the process and result of learning activity

c. Teacher gave the students homework.

\section{Post-test}

After the researcher taught the material for both experimental and control class, the researcher examined those classes using test called post-test. The instrument and item in experimental class were the same with control class. Then, the researcher compared the score of the sample classes. At the end, researcher tested hypothesis to find out the effect of Scavenger Hunt Game to experimental class. 


\section{FINDINGS}

The data of this research were the students' score in reading test, they were pre test and post test. The researcher chose the samples through purposive sampling technique by using the result of English final examination. The researcher got VIII 8 as experimental class and VIII 9 as control class. The researcher conducted try out at the other class that was VIII 10. Then, the items that too easy or poor were revised.

Before doing treatment at the experimental class, the researcher had done pre-test to both of classes to know the basic knowledge of the students' reading comprehension of descriptive text and also to determine if the samples had the same ability in reading comprehension and were homogenous.

Table 1: The Data of Students' Pre-test Score

\begin{tabular}{cccccc}
\hline Class & $\mathbf{N}$ & $\bar{x}$ & $\mathbf{S}$ & $\mathbf{S}^{2}$ & $\begin{array}{c}\text { Total \% } \\
\text { (Percentage) }\end{array}$ \\
\hline $\begin{array}{c}\text { VIII 8 } \\
\text { Experimental }\end{array}$ & 36 & 69,75 & 5,95 & 35,45 & $69,75 \%$ \\
\cline { 4 - 5 } $\begin{array}{c}\text { VIII 9 } \\
\text { Control }\end{array}$ & & 69,03 & 6,93 & 48,03 & $69,03 \%$ \\
\hline \multicolumn{5}{c}{ Difference } \\
\hline
\end{tabular}

Based on table above, it shown the difference score of pre-test on reading test between experimental class and control class was $\mathbf{0 , 7 2} \%$.It means that the ability on reading comprehension of descriptive text of both classes were homogenous.According to the result of the post-test in reading test, the researcher analyzed the mean score, standard deviation, and the variance of the data. The data of students' post-test score could be seen in the following table:

Table 2: The Data of Students' Post-test Score.

\begin{tabular}{|c|c|c|c|c|c|}
\hline Class & $\mathbf{N}$ & $\bar{x}$ & $\mathbf{S}$ & $S^{2}$ & $\begin{array}{c}\text { Total \% } \\
\text { (percentage) }\end{array}$ \\
\hline $\begin{array}{c}\text { VIII } 8 \\
\text { Experimental }\end{array}$ & \multirow{2}{*}{36} & 77,14 & 5,14 & 26,47 & $77,14 \%$ \\
\hline $\begin{array}{c}\text { VIII } 9 \\
\text { Control }\end{array}$ & & 72,94 & 6,32 & 39,88 & $72,94 \%$ \\
\hline & & ference & & & $4,20 \%$ \\
\hline
\end{tabular}

Based on the data above, the mean score of experimental class that was taught by using scavenger hunt game technique washigherthan the mean score of 
the control class taught by using three phase technique.It could be seen that the difference post-test score of experimental class from control class was about $4,20 \%$.

\section{Data Analysis}

In order to get the conclusion of the result of this research, the researcher used t-test statistical analysis. The data could be distributed normally and homogenously. In order to get the normality and homogeneity of the data, the researcher analyzed it by using some statistical analysis formulas.

\section{Normality Testing}

In order to analyze the normality of the data on students' reading comprehension of descriptive text on experimental and control class, the researcher got the data from both of the classes. The normality testing could be seen on the following table.

Table 3.Result of Normality Testing of the Sample

\begin{tabular}{|c|c|c|c|c|c|c|}
\hline Class & Test & $\mathbf{n}$ & $\mathbf{A}$ & $\begin{array}{c}\text { Critical } \\
\text { value of } \\
\text { accounting } \\
\text { (lo) }\end{array}$ & $\begin{array}{l}\text { Critical } \\
\text { value of } \\
\text { table(lt) }\end{array}$ & Distribution \\
\hline \multirow{2}{*}{$\begin{array}{l}\text { Experimental } \\
\text { VIII } 8\end{array}$} & Pre & \multirow{4}{*}{$\begin{array}{l}3 \\
6\end{array}$} & \multirow{4}{*}{$\begin{array}{l}0 \\
0 \\
5\end{array}$} & 0,1185 & \multirow{4}{*}{0,1477} & \multirow{4}{*}{ Normal } \\
\hline & Post & & & 0,1271 & & \\
\hline \multirow{2}{*}{$\begin{array}{l}\text { Control } \\
\text { VIII } 9\end{array}$} & Pre & & & 0,1411 & & \\
\hline & Post & & & 0,0939 & & \\
\hline
\end{tabular}

In pre-test and post-test,from the experimental class it was gotten that the calculated normalitycoefficient were $\mathrm{L}_{0}=0,1185$ and 0,1271 respectively; the table normalitycoefficient was $\mathrm{L}_{\mathrm{t}}=0,1477$ it means that $\mathrm{L}_{0}<\mathrm{L}_{\mathrm{t}}$. The data from the control class were $\mathrm{L}_{0}=0,1411$ and 0,0939 ; and $\mathrm{L}_{t}=0,1477$. It means that $\mathrm{L}_{0}<\mathrm{L}_{\mathrm{t}}$. According to the data analysis above the researcher concluded that the data from both experimental and control class were distributed normally.

\section{Homogenity Testing}

In order to know variance of the data of students' reading comprehension of descriptive text were same or not, the researcher analyzed it by using homogenity test. The result of homogenity testing could be seen on the following table. 
Table 4.Result of Homogenity Testing of the Samples

\begin{tabular}{|c|c|c|c|c|c|c|c|c|c|c|c|}
\hline \multirow{2}{*}{ Class } & \multirow{2}{*}{ Test } & \multirow{2}{*}{$\mathbf{N}$} & \multirow{2}{*}{$\mathbf{X}$} & \multirow{2}{*}{$\mathbf{S}$} & \multirow{2}{*}{$\mathbf{S}^{2}$} & \multicolumn{4}{|c|}{$\mathbf{F}_{\mathrm{cal}}$} & \multirow{2}{*}{$\mathbf{F}_{\text {tab }}$} & \multirow{2}{*}{ Variance } \\
\hline & & & & & & $\mathbf{F}_{1}$ & $\mathbf{F}_{2}$ & $F_{3}$ & $\mathbf{F}_{4}$ & & \\
\hline \multirow{2}{*}{$\begin{array}{l}\text { Experi } \\
\text { mental }\end{array}$} & Pre & \multirow{4}{*}{36} & $\begin{array}{l}69 \\
75\end{array}$ & 5,95 & $\begin{array}{l}35, \\
45\end{array}$ & \multirow{4}{*}{1,35} & \multirow{4}{*}{1,51} & \multirow{4}{*}{1,34} & \multirow{4}{*}{1,20} & \multirow{4}{*}{1,84} & \multirow{4}{*}{ Homogeneous } \\
\hline & Post & & $\begin{array}{l}77, \\
14\end{array}$ & 5,14 & $\begin{array}{l}26, \\
47\end{array}$ & & & & & & \\
\hline \multirow{2}{*}{ Control } & Pre & & $\begin{array}{l}69, \\
03\end{array}$ & 6,93 & $\begin{array}{l}48, \\
03\end{array}$ & & & & & & \\
\hline & Post & & $\begin{array}{l}72, \\
94\end{array}$ & 6,32 & $\begin{array}{l}39, \\
88\end{array}$ & & & & & & \\
\hline
\end{tabular}

From the data the researcher found that, $F_{\text {calculated }}$ in pre-test at both samples was $1,35, \mathrm{~F}_{\text {calculated }}$ in post-test at both samples was $1,51, \mathrm{~F}_{\text {calculated }}$ in prepost test at experimental class was 1,34 , and $F_{\text {calculated }}$ in pre-post test at control class was 1,20. Meanwhile, the $F_{\text {table }}(35: 35)$ was1,84with $\alpha=0,05$. The researcher concluded all of $F_{\text {calculate }} \leq F_{\text {table, }}$ it means that the variance of experimental and control class were homogenous.

\section{Hypothesis Testing}

In order to know whether there was any differentiation on students' reading comprehension of descriptive text at both in experimental and control class, the researcher did t-test statistical analysis. It could be seen on the following table:

Table 5.Result of t-Test

\begin{tabular}{|c|c|c|c|c|c|c|c|}
\hline Class & $\mathbf{n}$ & $\bar{x}$ & $S^{2}$ & A & $\mathbf{t}_{\mathrm{c}}$ & $t_{t}$ & Reference \\
\hline VIII 8 & \multirow{4}{*}{36} & & & \multirow{4}{*}{0,05} & \multirow{4}{*}{3,04} & \multirow{4}{*}{2,00} & Ho was \\
\hline Experiment & & 77,14 & 26,47 & & & & rejected and \\
\hline VIII 9 & & & & & & & Ha was \\
\hline Control & & 72,94 & 39,88 & & & & received \\
\hline
\end{tabular}

The researcher got the data $t_{\text {calculated }}=3,04$ and $t_{\text {table }}(70)=2,00, T_{\text {cal }}>T_{\text {table }}$. In conclusion, Ho was rejected and Ha was received.It means that students' reading comprehension of descriptive text taught by using scavenger hunt game technique was better than taught by using three phase technique. In other words there was a positive effect on students' reading comprehension of descriptive text taught by using scavenger hunt game technique. 


\section{DISCUSSION}

The findings of this research showed that using scavenger hunt technique could improve students' reading comprehension of descriptive text. This is proven by the three main findings that were discussed in this research. The first finding is based on the mean score of students' reading comprehension of descriptive texttaught by using Scavenger Hunt technique at experimental class. From the result showed that the difference of the students' mean score was improved from 69,75 at pre-test to 77,14 at post-test, with 7,39 improvement.

The second finding is based on the mean score of students' reading comprehension of descriptive texttaught by using Three Phase technique at control class.From the result showed that the difference of the students' mean score was improved from 69,03 at pre-test to 72,94 at post-test, with 3,91 improvement. But, it lesser than the improvement at experimental class.

The third finding is based on whether Scavenger Hunt technique gavea better effect on students' reading comprehension of descriptive text thanThree Phase technique.From the result showed that the difference improvement of the students' mean score was about 7,93 improvement in experimental class and 3,91 improvement in control class. It showed that, the students' reading comprehension of descriptive text taught by usingScavenger Hunt technique gavea better effect about 3,48 higher thanThree Phase technique.

Moreover, after conducting this research, the researcher found that the students at experimental class were so excited when the researcher explained that they would play a game and would compete with the other group in order to win the game and get a reward. They followed the teaching and learning process enthusiastically that the members of each group had cheers for their member who one by one searched for the flashcards. The students also have a fair competitive spirit that they competed to be the first group who successfuly found the flashcards and answered all of the questions. This technique made the students got information from each others by exchanging their ideas in the group while completing the answersheet about the text entitiled "My Favorite Mug", because of that their reading comprehension was improved.

Furthermore,Scavenger Hunt technique had createdan entertaining learning process for the students that when the members searched for flashcards, they tend to running to their other friends which made them laught. This technique had gave opportunity for students to interact with each other, that they answered the worksheet by discussing it in group. This finding supported the theory that proposed by Moore in Brown (1999) explains that, scavenger hunt is an entertaining and effective technique as well as to more traditional reading outcomes that when conducted in cooperative learning situations have the additional benefit of communicative learning. 
In addition, the existence of scavenger hunt technique in learning, especially in learning reading comprehension can give the students opportunity in sharing their ideas. In this case, when the students gave opinion or shared their ideas in groupin completing the worksheet. This finding supported the theory that is proposed by Barkley (2010) says that, scavenger hunt is activity to demonstrate the key elements of performing in an effective team by utilizing team work, communication, creative thinking, and instilling a spirit of cooperation and trust among team member.

Furthermore, based on the finding above, the researcher assumed thatapplyingscavenger hunt technique gave positive effect toward students' reading comprehension ofdescriptive text. There was a significant improvement of scavenger hunt technique toward students' reading comprehension.

In conclusion, scavenger hunt game technique is suggested to be used atschool especially for the teachers at SMP N 2 Kota Solok in teaching reading comprehensionof descriptive text. This technique can be used to create a lively classroom situation. It can make the students have fun and enjoy learning.

\section{CONCLUSION}

Based on the findings and discussion on the above, it could be concluded that using scavenger hunt game technique gave appositive effecton the students' reading comprehension of descriptive text. Moreover, it could be concluded that scavenger hunt game technique could also improve students'reading comprehension. Using scavenger hunt game technique could also improve students' motivation and students' participation during learning activity.

\section{REFERENCES}

Aminuddin. (2017). Improving Students' Speaking Skillby Using Scavenger Hunt Gamein MAN Kunir. Skripsi. Fakultas Tarbiyah dan Ilmu Keguruan

Tadris Bahasa Inggris.IAIN-tulungagun. Retrieved from http://repo.iaintulungagung.ac.id/id/eprint/4428

Anengsih, N. (2017). The Implementation of Treasure Hunt Games in Learning English Vocabulary at the First Grade of SMP N 1 Waled. Skripsi. English Languange Teaching Departement of Tarbiyah and Teaching Training Faculty Syekh Nurjati State Islamic Institute Cirebon. Retrieved from http://repository.syekhnurjati.ac.id/2338/1/NENG\%20AAN\%20ANENGS $\underline{\text { IH-min.pdf }}$

Aulia, A. (2013). The Effectiveness of Using Think Pairs Share Technique in Teaching reading Comprehension of Descriptive Text. Thesis. Universitas Mahaputra Muhammad Yamin..

Barkley, E., F. (2010). Student Engagement Techniques: A Handbook for College Facultty. San Fransisco: Jossey-Bassa 
Brown, I. (1999). Internet Scavenger Hunts: A Treasure of An Activity for Students Learning English. Sidney: ACTA.

Wulan, E, (2015). Teaching Vocabulary Using Scavenger Hunt to The First Grade Students at MI Negeri Surakarta in 2014/2015 Academic year. Thesis. School of teacher Training and Education Muhammadiyah University of Surakarta. Retrieved from http://eprints.ums.ac.id/id/eprint/32582

Ersoz, A. (2000) .Six Games for the EFL/ESL Classroom. The Internet TESL Journal, 6(6), 20-35

Koksal, O., Cekic, A. \& Behyan, O. (2014). Views of Turkish EFL Students with Regard to Learning Grammar with Games. International Journal on New Trend in Education and their Implications. 5(89), 89-99.

Kurniawati, C \& Marta, Y. (2008). Detik Detik Ujian Nasional Bahasa Inggris. Klaten: PT: Intan Pariwara.

Lee, S., K. (1995). Creative Games for the Language Class. 'Forum', 33(1), 25-38

Lu, Y. (2015). HUNT:Scavenger Hunt with Augmented Reality. Interdisciplinary Journal of Information, Knowledge, and Management. 10(3), 21-35.

Ly, P., \& Carr, A. (2010). The library scavenger hunt strikes back. CARL 2010 Conference Proceedings. Retrieved from http://www.carlacrl.org/Archives/ConferencesArchive/Conference10/2010proceedings/Pe arl-Ly_final.pdf

Meister, J., C. (2013). How Deloitte Made Learning a Game. Harvard Business Review. Retrieved from https://hbr.org/2013/01/how-deloitte-madelearning-a-g/ M

Mobile Technologies Group. (2004). Cell Phone Scavenger Hunt.Georgia Institute of Technology. Retrieved from http://mtg.gatech.edu/projects/ N

Nunan, D. (2005). Practical English Language Teaching Young Learners. New York: Mc Graw-Hill Companies

Nurhayati, G. (2017). The Influence of Treasure Hunt game in Improving Young Learners' Vocabulary Skill. English Education Study Program of Suryakencana University of Cianjur. Journal Kependidikan, 8(1), 37-51

Satya, A., A. (2016). The Effectiveness of Treasure Hunt Game for Teaching Vocabulary. Thesis. Fakultas Keguruan dan IlmuPendidikan UMP. Retrieved from http://repository.ump.ac.id/id/eprint/2479

Sari, R. (2016). Using Treasure Hunt Game to Improve the Seventh Grade students' Comprehension in Reading Desriptive Text at SMPN 2 Gona dang Tulungagung. Skripsi. Fakultas Tarbiyah dan Ilmu Keguruan Tadris

Bahasa Inggris IAIN Tulungagung. Retrieved from http://repo.iaintulungagung.ac.id/id/eprint/4253

Shaleha, W., N.(2017). Developing Students' Reading Comprehension through Scavenger Hunt Game. English language Teaching Society Journal, 5(2), $10-20$

Sigurdottir, S., D. (2010). The Use of Games in the Language Classroom. Thesis. Islandiae: Siggilum Universitatis Islandiae.

Starr, L. (1999). Scavenger Hunts: Searching for Treasure on the Internet! Education World Online. Retrieved from http://www.educationworld.com/a_curr/curr113.shtml 
Suryana, N. (2008). Genre:Reading Comprehension. Jakarta: Nobel Edumedia

Talton, J. O., Peterson, D. L., Kamin, S., Israel, D., \& Al-Muhtadi, J. (2006). Scavenger Hunt: Computer Science Retention through Orientation. Proceedings of the 37th SIGCSE Technical Symposium on Computer Science Education, 443-447

Wise, D. (2003). Great Big Book of Children's Games: Over 450 Indoor and Outdoor Games for Kids. New York: McGraw-Hill. Retrieved from http://en.m.wikipedia.org/wiki/Scavengerhunt

WRO. (2015). Treasure Hunt: Regular Category, Junior High School. Boston: World Robot Olympiad 